\title{
Idelalisib at the Crossroads of B-Cell Lymphoproliferative Disorders
}

\author{
Salih AKSU ${ }^{1}$, Orhan AYYILDIZ ${ }^{2}$, Sezgin ETGUL ${ }^{1}$, Hakan GOKER ${ }^{1}$, Gursel GUNES ${ }^{1}$, \\ Ibrahim C. HAZNEDAROGLU ${ }^{1}$, Osman ILHAN ${ }^{3}$, Leyla G. KAYNAR ${ }^{4}$, Umit Y. MALKAN ${ }^{1}$, \\ Evren OZDEMIR ${ }^{5}$, Guray SAYDAM ${ }^{6}$, Nilgun SAYINALP', Fahri SAHIN ${ }^{6}$, \\ Mehmet TURGUT ${ }^{7}$, Ali UNAL ${ }^{4}$
}

\author{
${ }^{1}$ Hacettepe University Faculty of Medicine Department of Hematology, Ankara \\ ${ }^{2}$ Dicle University Faculty of Medicine Department of Hematology, Diyarbakır \\ ${ }^{3}$ Ankara University Faculty of Medicine Department of Hematology, Ankara \\ ${ }^{4}$ Erciyes University Faculty of Medicine Department of Hematology, Kayseri \\ ${ }^{5}$ Hacettepe University Faculty of Medicine Department of Oncology, Ankara \\ ${ }^{6}$ Ege University Faculty of Medicine Department of Hematology, Izmir \\ ${ }^{7}$ Ondokuz Mayıs University Faculty of Medicine Department of Hematology, Samsun, TURKEY
}

\begin{abstract}
Phosphatidylinositol 3-kinases (PI3Ks) are considered as lipid kinases that are very active in the pathobiology of lymphoproliferative disorders (LPDs). Idelalisib, a selective inhibitor of the delta isoform of PI3K, provides significant clinical efficacy and has an acceptable side-effect profile in the treatment of B-LPDs. The aim of this review is to outline the pharmacobiological basis of idelalisib that is located at the crossroads of B-LPDs. The PI3K signaling pathway with downstream targets including Akt is involved in hematologic malignancies and lymphomas. Idelalisib has been most widely studied in chronic lymphoid leukemia (CLL) and B-lymphoma. The activity of idelalisib in high-risk FL with early relapse following front line immunochemotherapy was recently shown. The unique immunological toxicity pattern of idelalisib was also decribed in this review. Further clinical investigations will help for the better selection of the subsets of the patients with B-LPD that would be best candidates for the clinical utilization of idelalisib. Other indications such as marginal zone lymphoma, mantle cell lymphoma, Waldenstrom's Macroglobulinemia and other B-cell disorders could likely to be expanded. Future clinical and experimental data combined with the next-generation genomics strategies and personalized medicine for the treatment of malignant disorders will enlightened us for better placement of idelalisib in the treatment algorithm of the patients.
\end{abstract}

Keywords: Idelalisib, B-cell, Lymphoproliferative disorders

\section{ÖZET}

\section{B-Hücreli Lenfoproliferatif Hastalıkların Dönüm Noktası İdelalisib}

Fosfatidilinositol 3-kinaz (PI3K)'lar lenfoproliferatif hastalıklar (LPH)'ın patobiyolojisinde oldukça aktif olan lipid kinazlardandırlar. PI3K'nın delta izoformunun selektif bir inhibitörü olan İdelalisib, B-LPH'ın tedavisinde önemli klinik etkinlikle beraber kabul edilebilir bir yan etki profiline sahiptir. Bu derlemede, B-LPH'ın dönüm noktasında yer alan İdelalisib'in farmakobiyolojik temeli vurgulanmaya çalışılmıştır. Hematolojik malignansi ve lenfomalarda, Akt'yi de içeren PI3K yolağındaki hedefler rol almaktadır. İdelalisib yaygın olarak kronik lenfositik lösemi ve B-lenfoma çalışmalarında araştııımıştır. İdelalisib'in ilk sıra immünokemoterapi ardından erken relaps olan yüksek riskli foliküler lenfoma hastalarındaki etkinliği son zamanlarda ortaya konmuştur. Bu derlemede ayrıca İdelalisib'in benzersiz immünolojik toksisite paterni de ele alınmıştır. İerdeki klinik araştırmalar, İdelalisib'in klinikteki kullanımı için aday olacak B-LPH hastalarının seçiminde yardımcı olacaktır. İdelalisib'in genişletilmiş endikasyonları arasında marjinal zon lenfoma, mantle hücreli lenfoma, Waldenström Makroglobinemisi ve diğer B-hücreli hastalıklar sayılabilir. Gelecekteki klinik ve deneysel verilerin yeni nesil genomik stratejileri ile birleştirilmesi ve malign hastalıkların tedavisinde kişiselleştirilmiş ilaçların gelişimi, İdelalisib'in hastaların tedavi algoritmasındaki yerinin belirlenmesini sağlayacaktır.

Anahtar Kelimeler: İdelalisib, B-hücre, Lenfoproliferatif hastalıklar 


\section{INTRODUCTION}

Phosphatidylinositol 3-kinases (PI3Ks) are considered as lipid kinases that are very active in the pathobiology of lymphoproliferative disorders (LPDs). ${ }^{1} \mathrm{PI} 3 \mathrm{Ks}$ regulate diverse cellular processes including proliferation, adhesion, survival, and motility in LPDs. Thus, dysregulated PI3K pathway signaling occurs in the majority of the LPDs (1). Idelalisib, a selective inhibitor of the delta isoform of PI3K, provides significant clinical efficacy and has an acceptable side-effect profile in the treatment of B-LPDs. ${ }^{2}$ The aim of this review is to outline the pharmacobiological basis of idelalisib that is located at the crossroads of B-LPDs. Targeted therapy of B-LPDSs promise a chemotherapyfree future for the patients based on the results fo the current clinical trials. ${ }^{3,4}$ Idelalisib will shape the future clinical landscape of B-cell malignancies. ${ }^{5}$ The recently approved small molecule kinase inhibitors are effective treatment options for elderly LPD patients with decreased tolerance for aggressive regimens and in patients with poor prognostic features who do not benefit from conventional chemoimmunotherapy regimens. ${ }^{6}$

\section{Idelalisib, PI3Ks and B-lymphoproliferative Disorders}

The PI3K signaling pathway with downstream targets including Akt is involved in hematologic malignancies and lymphomas. The development of PI3K inhibitors, particularly idelalisib, directed toward this pathway with confirmed clinical efficacy. ${ }^{7}$ The importance of the PI3K signaling pathway, main location for idelalisib, in B-LPDs is depicted in Figure 1.

\section{Idelalisib in Chronic Lymphoid Leukemia}

Idelalisib has been most widely studied in chronic lymphoid leukemia (CLL) and B-lymphoma in numerous clinical trials..$^{5,6,8-17}$ Recently published mature results of the initial treatment of CLL with idelalisib plus rituximab demonstrated that the combination is extremely effective with manageable toxicity in older CLL patients. ${ }^{15,18}$

O'Brien et al presented the first clinical trial of idelalisib with rituximab for the initial therapy of CLL in patients with a median age of 71 years, $42 \%$ of whom had advanced-stage disease. ${ }^{15}$ The overall

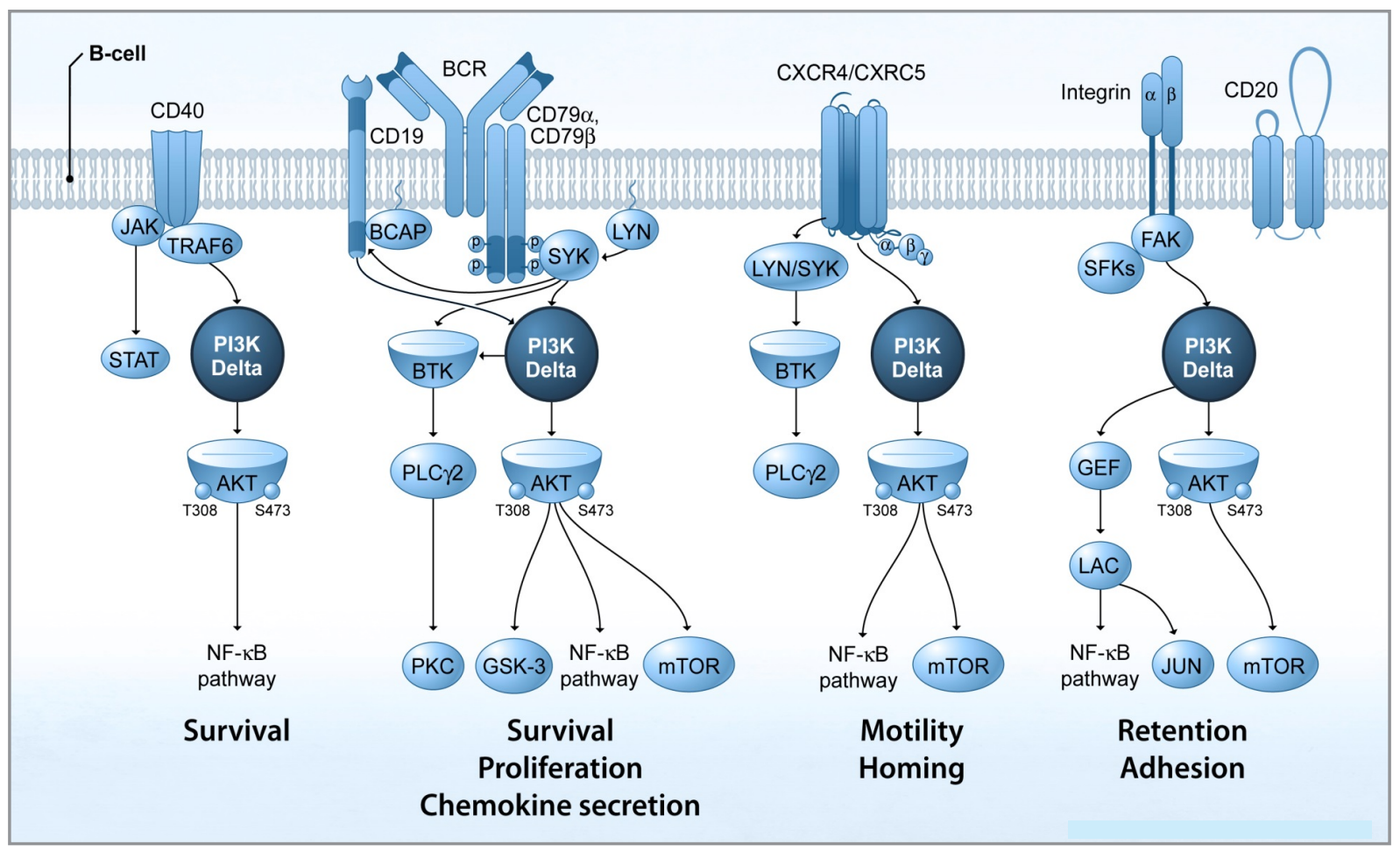

Figure 1. The importance of the PI3K signaling pathway in B- lymphoproliferative disorders 


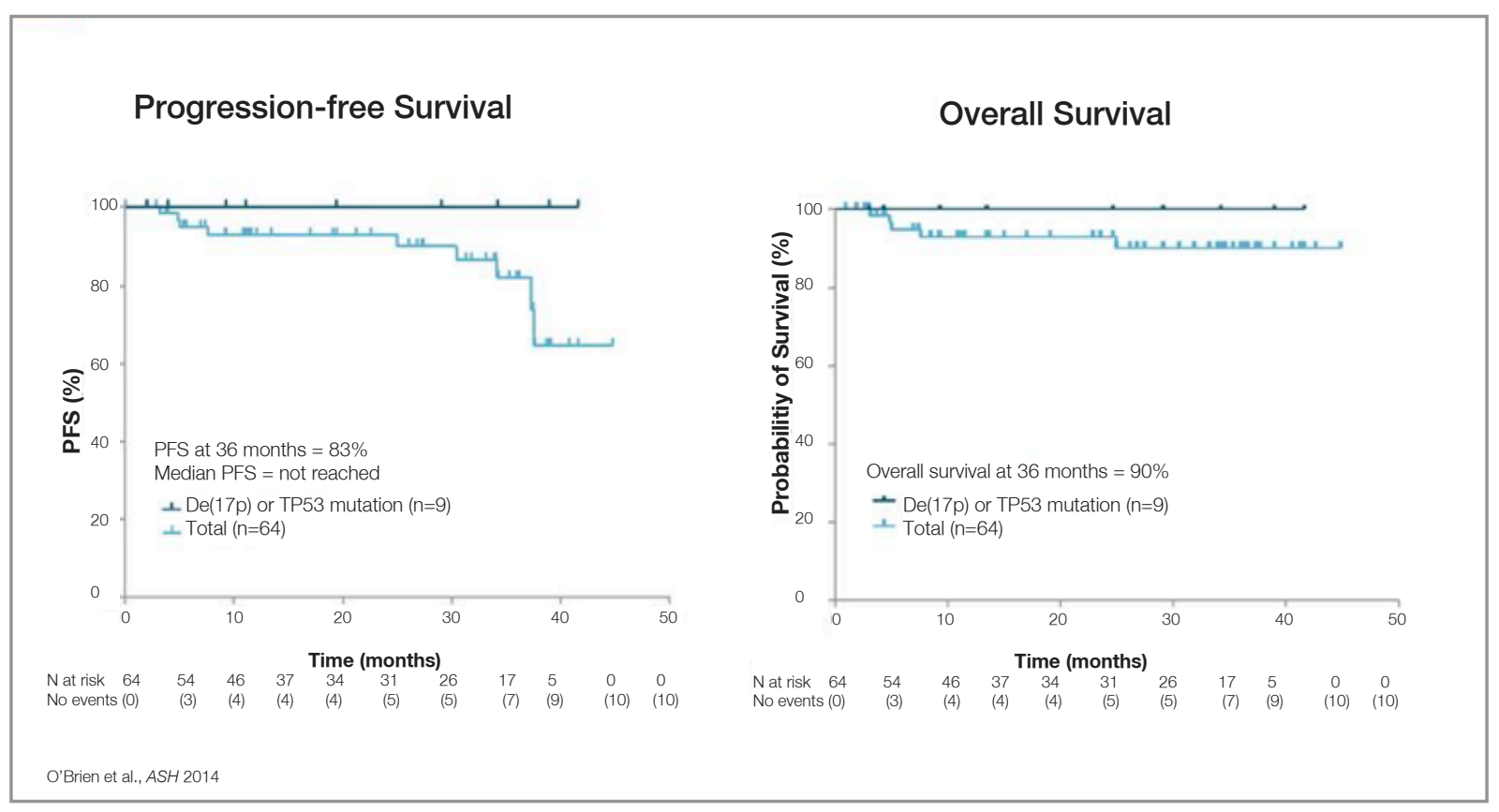

Figure 2. The progression-free survival (PFS) is $83 \%$ at 36 months with idelalisib in the front-line study of chronic lymphoid leukemia (CLL).

response rate is $97 \%$, with $19 \%$ being complete responders. The progression-free survival (PFS) is an impressive $83 \%$ at 36 months, with only 4 events of disease progression, despite only 23 of 64 patients currently continuing on idelalisib. ${ }^{15,18}$ The effectiveness of idelalisib is particularly striking in patients with high-risk cytogenetic abnormalities like 17p deletion and in older CLL patients in whom chemoimmunotherapy is apparently less well-tolerated. Among the highest-risk TP53-mutated patients $(n=9)$, the overall response rate is $100 \%$ and none have progressed, consistent with the known excellent activity of idelalisib in relapsed patients in this high risk group (Figure 2).

On the other hand in the patients with heavily pre-treated high-risk relapsed CLL not suitable for chemotherapy, idelalisib added to Rituximab improved PFS including patients with del(17p)/ TP53 mutation or IGHV mutational status "unmutated". ${ }^{17,19-26}$ The idelalisib plus rituximab combination had improved overall response rate and lymph node response, improved overall survival (OS) and quality of life (QoL) independent of poor prognostic factors of CLL at the same study an acceptable safety profile. The most impressive find- ing was that idelalisib and rituximab treatment had similar efficacy regardless of the presence of $17 p$ deletion or IGHV mutational status. OS is higher for patients on idelalisib+rituximab despite crossover in extension design. Favorable benefit/risk ratio is maintained during the longer follow-up of the study. ${ }^{17,19-26}$ Figure 3 illustrates the superiority of idelalisib+rituximab combination versus the control arm in terms of PFS.

Idelalisib in combination with bendamustin + rituximab (BR) is superior to BR alone, reducing the risk of both disease progression and death, increasing PFS and OS, and with a safety profile consistent with prior reported studies. Median PFS of IDELA + BR vs BR + placebo: 23 mo vs 11 mo $(\mathrm{HR}=0.33 ; \mathrm{p}<0.0001)$, median OS of IDELA + BR vs $\mathrm{BR}+$ placebo not reached for either arm $(\mathrm{HR}=$ $0.55 ; \mathrm{p}=0.008)$. Rai stage III/IV 46\%; median time since completion of last prior therapy 16 months; patients with $\operatorname{del}(17 \mathrm{p}) / \mathrm{p} 53$ mut $32.9 \%$, patients with unmutated IGHV $83.2 \%$, patients with refractory disease $29.8 \%$, median number of prior therapies: 2 (range: 1-13). Those results were consistent across pts with high-risk features. The addition of idelalisib to BR was also beneficial in patients 


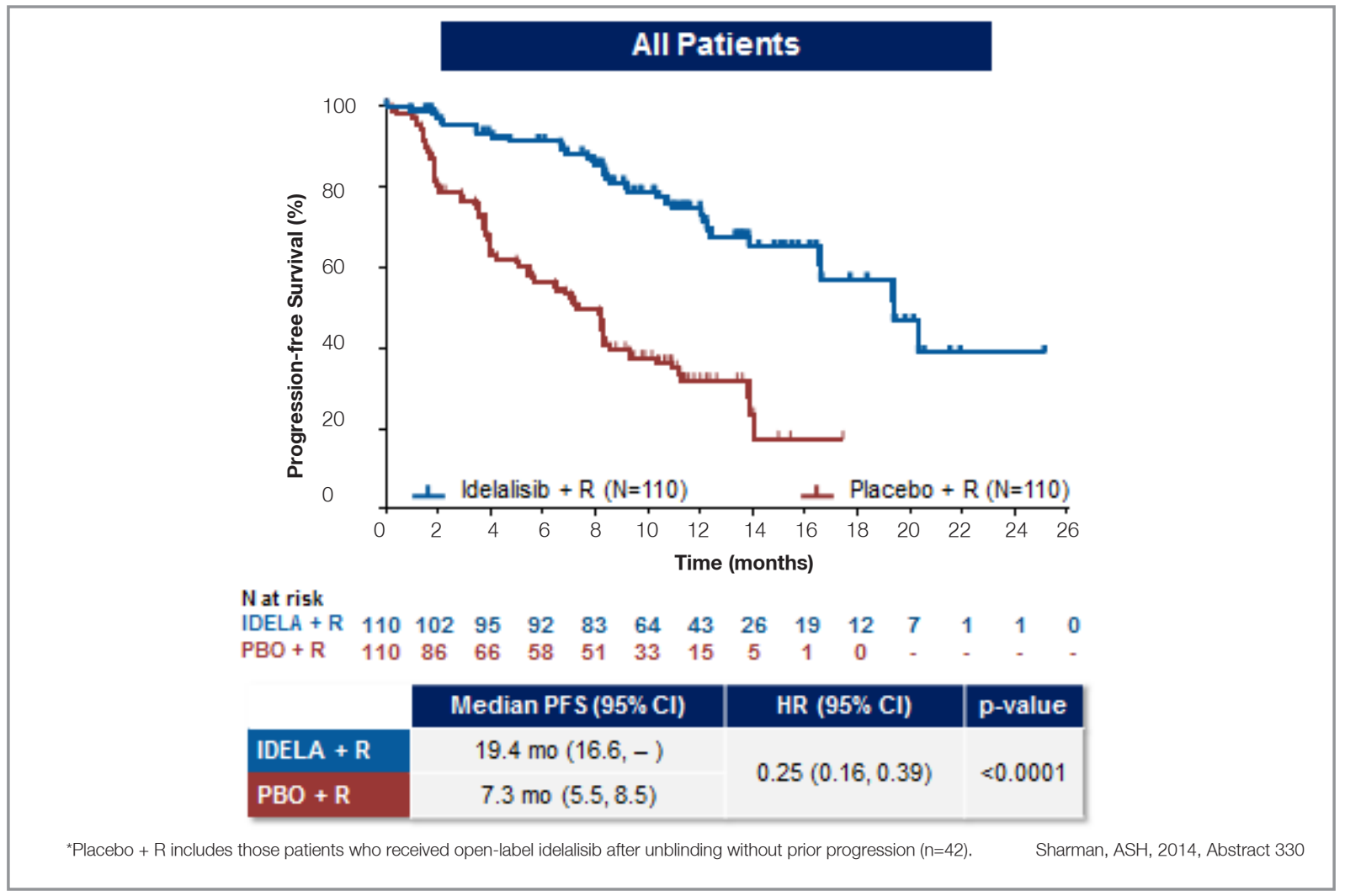

Figure 3. The progression-free survival (PFS) of idelalisib+rituximab combination is superior versus the control arm in heavily pretreated high-risk relapsed chronic lymphoid leukemia (CLL) not suitable for chemotherapy.

without del(17p)/TP53mut. This kind of idelalisib regimen represents an important new option for the patients with relapsed and resistant CLL. ${ }^{16}$

The complexity of CLL with respect to different chromosomal aberrations, lack of a common aberrant signaling pathway activation, and associated immune suppression of the disease seems to be challenging for the targeted therapies. ${ }^{27}$ Current CLL trials of idelalisib ${ }^{17,19-26}$ appear to be overcoming this obstacle. The possibility of a chemotherapy-free treatment approach may be possible not only for CLL but also other B-LPDs. ${ }^{3}$

\section{Idelalisib in B-lymphoma}

Follicular lymphoma (FL) is the most common indolent non-Hodgkin lymphoma (NHL) with a heterogenous natural history of disease and a median survival of 8 to 12 years. The activity of idelalisib in high-risk FL with early relapse following front line immunochemotherapy was recently shown. ${ }^{10}$
The study subgroup of 46 patients with FL and having received first-line immunochemotherapy, of which 37 experienced early disease progression, defined as starting second-line treatment within 24 months of initial first-line treatment. PFS and OS following initiation of immunochemotherapy and idelalisib were assessed in this small subset study. ${ }^{10}$ Best responses included $5(13.5 \%)$ patients with CR, 16 (43.2\%) with PR, 2 (5.4\%) with SD, and 1 $(2.7 \%)$ with PD. Estimated probabilities of survival and progression-free status at 2 years following initiation of idelalisib were $79 \% \pm 7 \%$ and $29 \% \pm 10 \%$, respectively. Thus, idelalisib may have significant clinical activity in high-risk and doubly-refractive FL following early relapse status post first-line immunochemotherapy. ${ }^{10}$

Mature follow-up data from a phase 2 study of idelalisib in patients with double (rituximab and alkylating agent)-refractory indolent B-NHL (R/R iNHL) were established. Patients had received a median of 4 prior regimens (range, 2 to 12), with 


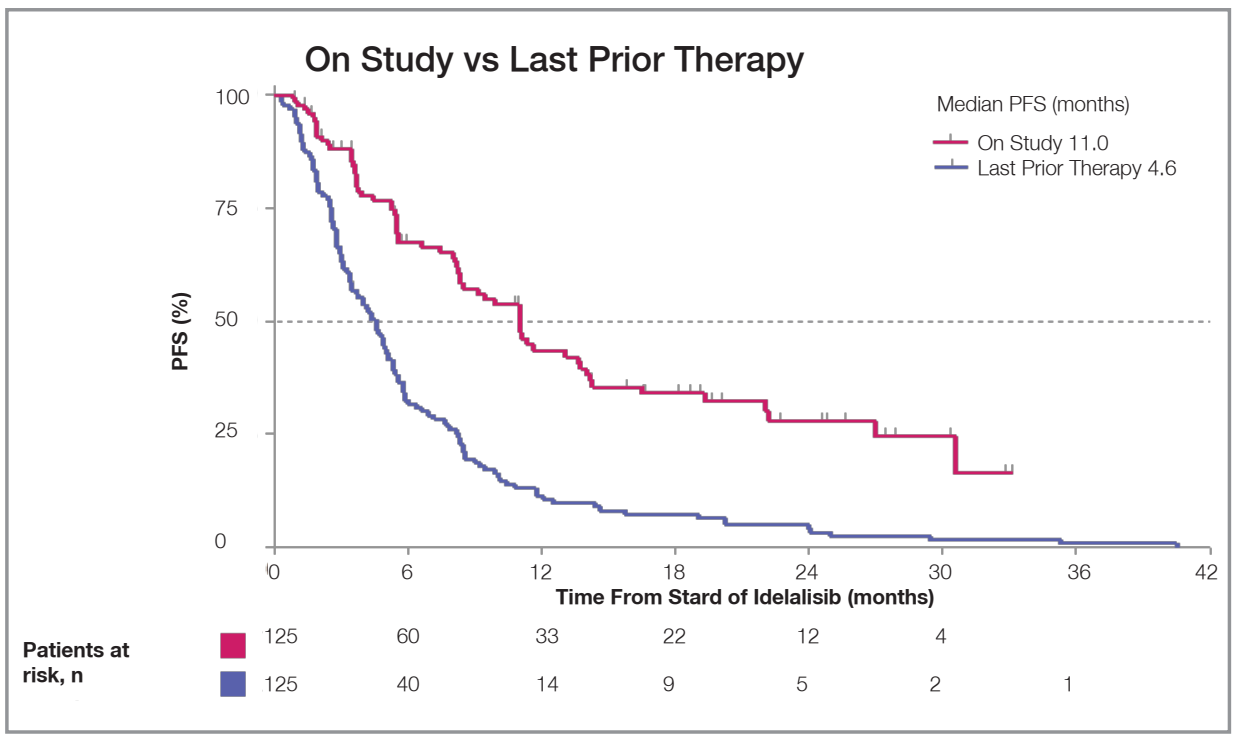

Figure 4. The safety profile of Idelalisib on continuous therapy was manageable with effective response in lymphoma

73 patients $(58 \%)$ having received 4 or more prior regimens. ${ }^{28}$ Idelalisib demonstrated high response rates (ORR 58\%) in patients with R/R iNHL. Response durations were prolonged (median 12.5 months). With a median 9.7 months follow-up; the median progression-free survival was 11.0 months (wh, with $47 \%$ of the patients remaining progression free at 48 weeks. The median overall survival was 20.3 months, and overall survival at 1 year was estimated to be $80 \%$. The safety profile of idelalisib in these patients on continuous therapy was manageable (Figure 4). ${ }^{28}$

Likewise, durable responses following the treatment with idelalisib in combination with rituximab, bendamustine, or both, in recurrent iNHL were also reported in phase I/II trials. ${ }^{29}$ Idelalisib in combination therapy for patients with $\mathrm{R} / \mathrm{R}$ iNHL resulted in high response rates (ORR of $81 \%$ ), durable response (median PFS of 37 months and DOR at 36 months of 55\%), manageable safety profile with treatment $>3$ years, with no unexpected toxicities. This data provides strong support for Phase 3 trials of idelalisib in combination with rituximab or bendamustine/rituximab for the treatment of patients with R/R iNHL. ${ }^{29}$

\section{The Unique Immunological Toxicity Pattern of Idelalisib}

In the clinical idelalisib trials performed in the $\mathrm{R} / \mathrm{R}$ setting, the ORR was $70-80 \%$, while the frequency of significant toxicity was easily manageable (grade $\geq 3$ transaminitis $14 \%$, pneumonitis $3 \%$, grade $\geq 3$ diarrhea $14 \%) .{ }^{30}$ However, the use of idelalisib as first-line therapy in CLL results in more frequent and severe toxicities than its use in the R/R setting. Idelalisib toxicity has an immune-mediated mechanism. The delayed time to onset, the immune cell infiltrate in biopsies of affected organs (such as the colonic mucosa) and abatement of toxicity with immunosuppressants have all supported the unique immunological toxicity pattern of idelalisib. ${ }^{31}$ Affected CLL patients had depressed Treg functionality at baseline and lost marker of Treg activation after idelalisib therapy. ${ }^{31}$ On the other hand, previous studies ${ }^{32}$ disclosed that CD4+CD25+ T cells were elevated in inflammatory bowel disease (IBD) suggesting a partial role of activated $\mathrm{T}$ cell response in the disease pathophysiology. Thus, the conclusion that $\mathrm{CD} 4+\mathrm{CD} 25+$ regulatory $\mathrm{T}$ cells may play a key role in the immunopathogenesis of $\mathrm{IBD}^{32}$ shall be further searched for the immunitymediated colitis associated with the idelalisib as well. ${ }^{33}$ Non-immune toxicity profile of idelalisib is expected and usually easier to manage. .,30,34-45 $^{\text {. }}$ 


\section{Expanding Spectrum of Idelalisib and PI3K Pathway in B-lymphoproliferative Disorders}

In USA/FDA; Idelalisib is indicated in combination with rituximab for patients with relapsed chronic lymphocytic leukemia (CLL) for whom rituximab alone would be considered appropriate therapy and as monotherapy for patients with relapsed follicular B-cell non-Hodgkin lymphoma (FL) and small lymphocytic lymphoma (SLL) who have received at least two prior systemic therapies.

In Europe/EMA; Idelalisib has been approved for use in combination with rituximab for patients who have received at least one prior therapy; or as firstline treatment in the presence of $17 \mathrm{p}$ deletion or TP53 mutation in patients unsuitable for chemoimmunotherapy for the treatment of CLL. For the treatment of FL, Idelalisib has been approved as a monotherapy in patients who are refractory to two prior lines of treatment. ${ }^{14,46,47}$ Further clinical investigations will help for the better selection of the subsets of the patients with B-LPD that would be best candidates for the clinical utilization of idelalisib. Other indications such as marginal zone lymphoma ${ }^{13}$, mantle cell lymphoma ${ }^{48}$, Waldenstrom's Macroglobulinemia ${ }^{49,50}$, and other B-cell disorders $^{51}$ could likely to be expanded. Future clinical and experimental data combined with the next-generation genomics strategies and personalized medicine for the treatment of malignant disorders will enlightened us for better placement of idelalisib in the treatment algorithm of the patients.

\section{REFERENCES}

1. Akinleye A, Avvaru P, Furqan M, et al. Phosphatidylinositol 3-kinase (PI3K) inhibitors as cancer therapeutics. J Hematol Oncol 6: 88, 2013.

2. Fruman DA, Cantley LC. Idelalisib - A PI3K delta Inhibitor for B-Cell Cancers. NJEM 370: 1061-1062, 2014.

3. Cheson BD. CLL and NHL: the end of chemotherapy? Blood 123: 3368-3370, 2014.

4. Wendtner CM. Chemotherapy-free treatment of chronic lymphocytic leukemia? Dtsch Med Wochenschr 138: 2104-2106, 2013.

5. Yang QS, Modi P, Ramanathan S, et al. Idelalisib for the treatment of B-cell malignancies. Expert Opin Orphan Drugs 3: 109-123, 2015.
6. Zelenetz AD, Gordon LI, Wierda WG, et al. Chronic Iymphocytic leukemia/small Iymphocytic lymphoma, Version 1.2015. J Natl Compr Canc Netw 13: 326-362, 2015.

7. Curran E, Smith SM. Phosphoinositide 3-kinase inhibitors in lymphoma. Curr Opin Oncol 26: 469-475, 2014.

8. Coutre S, Barrientos JC, Brown JR, et al. Safety of idelalisib in B-cell malignancies: Integrated analysis of eight clinical trials. J Clin Oncol 33: 18030, 2015

9. Davies A. Idelalisib for relapsed/refractory indolent B-cell nonHodgkin's lymphoma: an overview of pharmacokinetics and clinical trial outcomes. Expert Rev Hematol 8: 581-593, 2015.

10. Gopal AK, Kahl BS, Flowers C, et al. Activity of idelalisib in high-risk follicular lymphoma with early relapse following front line immunochemotherapy. Blood 126: 2744, 2015.

11. Kahl BS, Spurgeon SE, Furman RR, et al. A phase 1 study of the PI3K delta inhibitor idelalisib in patients with relapsed/refractory mantle cell lymphoma (MCL). Blood 123: 3398-3405, 2014.

12. Kinoshita T, Fukuhara N, Nagai $H$, et al. Phase $1 \mathrm{~b}$ and pharmacokinetic study of idelalisib in Japanese patients with relapsed or refractory (R/R) indolent B-Cell non-Hodgkin lymphoma (iNHL) or chronic lymphocytic leukemia (CLL). Blood 126: 5089, 2015.

13. Martin P, Armas A, Gopal AK, et al. Idelalisib monotherapy and durable responses in patients with relapsed or refractory marginal zone lymphoma (MZL). Blood 126: 1543, 2015.

14. Miller BW, Przepiorka D, de Claro RA, et al. FDA Approval: Idelalisib monotherapy for the treatment of patients with follicular lymphoma and small lymphocytic lymphoma. Clin Cancer Res 21: 1525-1529, 2015.

15. O'Brien SM, Lamanna N, Kipps TJ, et al. A phase 2 study of idelalisib plus rituximab in treatment-naïve older patients with chronic lymphocytic leukemia. Blood 126: 2686-2694, 2015.

16. Zelenetz AD, Robak T, Coiffier B, et al. Idelalisib plus bendamustine and rituximab (BR) is superior to $\mathrm{BR}$ alone in patients with relapsed/refractory chronic lymphocytic leukemia: Results of a phase 3 randomized double-blind placebo-controlled study. Blood 126: LBA-5, 2015.

17. Stilgenbauer S, Hallek MJ, Coutre SE, et al. Efficacy of idelalisib in CLL subpopulations harboring del(17p) and other adverse prognostic factors: Results from a phase 3, randomized, double-blind, placebo-controlled trial. Oncol Res Treat 37: 184, 2014.

18. Brown JR. Idelalisib has CLL on the run! Blood 126: 2656 $2657,2015$.

19. Eradat HA, Coutre SE, Barrientos JC, et al. A phase III, randomized, double-blind, placebo-controlled study evaluating the efficacy and safety of idelalisib (GS-1101) in combination with bendamustine and rituximab for previously treated chronic lymphocytic leukemia (CLL). J Clin Oncol 31: 7133, 2013.

20. Eradat HA, Robak T, Delgado J, et al. A phase 3, randomized, double-blind, placebo-controlled study evaluating the efficacy and safely or idelalisib (GS-1101) in combination with bendamustine and Minimal) for previously treated chronic lymphocytic leukemia (CLL). J Clin Oncol 32: 7123, 2014. 
21. Furman RR, Sharman JP, Coutre SE, et al. A Phase 3, randomized, double-blind, placebo-controlled study evaluating the efficacy and safety of idelalisib and rituximab for previously treated patients with chronic lymphocytic leukemia (CLL). Blood 122: LBA-6, 2013.

22. Ghia $\mathrm{P}$, Hillmen $\mathrm{P}, \mathrm{Kim} \mathrm{Y}$, et al. Overall survival analysis adjusting for treatment effect after crossover in a phase 3 study evaluating idelalisib in combination with rituximab in relapsed chronic lymphocytic leukemia (CII). Haematologica 100: 315, 2015

23. Ghia P, O'Brien SM, Hillmen $P$, et al. Health-related quality of life (HRQL) impact of idelalisib (IDELA) in patients (pts) with relapsed chronic lymphocytic leukemia (CLL): Phase 3 results. J Clin Oncol 32: 7099, 2014.

24. Salles GA, Lamanna N, Amin BR, et al. A phase 3, randomized, double-blind, placebo-controlled study evaluating the efficacy and safely of idelalisib on eninhination with bendamustine and rituximab for previously untreated chronic lymphocytic leukemia. J Clin Oncol 32: $7123,2014$.

25. Sharman JP, Coutre SE, Furman RR, et al. Second interim analysis of a phase 3 study of idelalisib (ZYDELIG®) plus rituximab $(R)$ for relapsed chronic lymphocytic leukemia (CLL): Efficacy analysis in patient subpopulations with Del(17p) and other adverse prognostic factors. Blood 124: 330, 2014.

26. Stilgenbauer S, Coutre SE, Furman RR, et al. Efficacy of ideIalisib in Cll subpopulations harboring Del(17p) and other adverse prognostic factors: Results from a phase 3, randomized, double-blind, placebo-controlled trial. Haematologica 99: 521, 2014.

27. Awan FT, Byrd JC. New strategies in chronic lymphocytic leukemia: Shifting treatment paradigms. Clin Cancer Res 20: 5869-5874, 2014.

28. Gopal AK, Kahl BS, de Vos S, et al. Mature follow up from a phase 2 study of PI3K-Delta inhibitor idelalisib in patients with double (rituximab and alkylating agent)-refractory indolent BCell non-Hodgkin lymphoma (iNHL). Blood 124: 1708, 2014.

29. de Vos S, Wagner-Johnston ND, Coutre SE, et al. Durable responses following treatment with the PI3K-Delta inhibitor idelalisib in combination with rituximab, bendamustine, or both, in recurrent indolent non-Hodgkin lymphoma: Phase I/II Results. Blood 124: 3063, 2014.

30. Coutre S, Barrientos J, Brown J, et al. Safety of idelalisib in B-cell malignancies: Integrated analysis of eight clinical trials. Haematologica 100: 225, 2015.

31. Lampson BL, Matos T, Kim HT, et al. Idelalisib given front-Line for the treatment of chronic lymphocytic leukemia results in frequent and severe immune-mediated toxicities. Blood 126: 497, 2015.

32. Kekilli M, Tunc B, Beyazit $Y$, et al. Circulating CD4+CD25+ regulatory $T$ cells in the pathobiology of ulcerative colitis and concurrent primary sclerosing cholangitis. Dig Dis Sci 58: 1250-1255, 2013.

33. Louie CY, DiMaio MA, Matsukuma KE, et al. Idelalisib-associated enterocolitis: Clinicopathologic features and distinction from other enterocolitides. Am J Surg Pathol 39: 1653-1660, 2015.
34. Jin F, Robeson M, Zhou HF, et al. The pharmacokinetics and safety of idelalisib in subjects with severe renal impairment. Blood; 122: 5572, 2013.

35. Jin F, Robeson M, Zhou HF, et al. The pharmacokinetics and safety of idelalisib in subjects with moderate or severe hepatic impairment. Blood 122: 5571, 2013.

36. Jin F, Robeson M, Zhou HF, et al. The pharmacokinetics and safety of idelalisib in subjects with severe renal impairment. Cancer Chemother Pharmacol 76: 1133-1141, 2015.

37. Jin F, Robeson M, Zhou HF, et al. The pharmacokinetics and safety of idelalisib in subjects with moderate or severe hepatic impairment. J Clin Oncol 32: 15, 2014.

38. Jin F, Robeson M, Zhou HF, et al. The pharmacokinetics and safety of idelalisib in subjects with moderate or severe hepatic impairment. J Clin Pharmacol 55: 944-952, 2015.

39. Jones JA, Wach M, Robak T, et al. Results of a phase III randomized, controlled study evaluating the efficacy and safety of idelalisib (IDELA) in combination with ofatumumab (OFA) for previously treated chronic lymphocytic leukemia (CLL). J Clin Oncol 33: 7023, 2015.

40. Leonard J, Zinzani PL, Jurczak W, et al. A phase III, randomized, double-blind, placebo-controlled study evaluating the efficacy and safety of idelalisib (GS-1101) in combination with rituximab for previously treated indolent non-Hodgkin lymphomas (iNHL). J Clin Oncol 31: 8617, 2013.

41. Liewer S, Huddleston AN. Oral targeted therapies: managing drug interactions, enhancing adherence and optimizing medication safety in lymphoma patients. Expert Rev Anticancer Ther 15: 453-464, 2015.

42. Papadopoulos KP, Egile C, Ruiz-Soto R, et al. Efficacy, safety, pharmacokinetics and pharmacodynamics of SAR245409 (voxtalisib, XL765), an orally administered phosphoinositide 3-kinase/mammalian target of rapamycin inhibitor: a phase 1 expansion cohort in patients with relapsed or refractory lymphoma. Leuk. Lymphoma 56: 1763-1770, 2015.

43. Salles GA, Ervin TJ, Dichmann R, et al. A phase 3, randomized, double-blind, placebo-controlled study evaluating the efficacy and safety of idelalisib in combination with rituximab for previously treated indolent non-Hodgkin lymphomas (iNHL). J Clin Oncol 32: 15, 2014.

44. Salles GA, Schuster SJ, De Vos S, et al. Idelalisib efficacy and safety in follicular lymphoma patients from a phase 2 study. J Clin Oncol 33: 8529, 2015.

45. Zinzani P, Salles G, Schuster SJ, et al. Idelalisib efficacy and safety in follicular lymphoma patients from a phase 2 study. Haematologica 100: 272, 2015.

46. Sanford DS, Wierda WG, Burger JA, et al. Three Newly Approved Drugs for Chronic Lymphocytic Leukemia: Incorporating Ibrutinib, Idelalisib, and Obinutuzumab into Clinical Practice. Clin Lymphoma Myeloma Leuk; 15: 385-391, 2015.

47. Markham A. Idelalisib: First Global Approval. Drugs 74: 1701 1707, 2014.

48. Matilla BN, Garcia-Marco JA. Mantle cell lymphoma: Towards a personalized therapeutic strategy? Med Clin (Barc) 144: 553-559, 2015 
International Journal of Hematology and Oncology

49. Coutre S, Leonard J, Flowers C, et al. Idelalisib monotherapy results in durable responses in patients with relapsed or refractory Waldenstrom's Macroglobulinemia (Wm). Haematologica 100: 273, 2015.

50. Coutre S, Leonard J, Flowers C, et al. Idelalisib monotherapy and durable responses in patients with relapsed or refractory Waldenstroms Macroglobulinemia (WM). J Clin Oncol 33: 8532, 2015.

51. Puri KD, Di Paolo JA, Gold MR. B-Cell Receptor signaling inhibitors for treatment of autoimmune inflammatory diseases and B-cell malignancies. Int Rev Immunol 32: 397-427, 2013.

\section{Correspondence}

\section{Dr. Salih AKSU}

Hacettepe Üniversitesi Tıp Fakültesi

İç Hastalıkları Anabilim Dalı

Hematoloji Bilim Dalı

TR-06100, Sinhiye, ANKARA / TURKEY

Tel: (+90-312) 3051543

email: saksu@hacettepe.edu.tr 